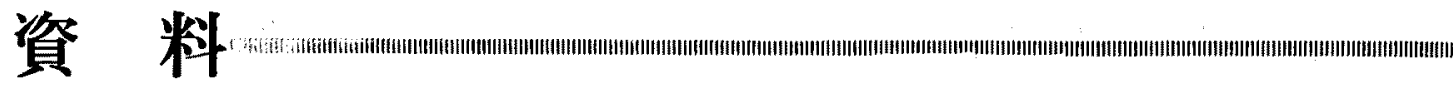

\title{
特許からみた「ソ連における合成ゴム製造技術 及び合成ゴムを主体とする組成物の進歩」
}

(1976年 1 月～6月)

はじめに

昨年，本誌（日本ゴム協会誌，49 810 813 (1976)) に1975年 7 月 12月までの期間中に公告されたソ連特許 （発明者証む含む）から合成ゴム製造技術及び合成ゴム を主体とする組成物の分野に属するむののうち，代表的 なものを抄録し紹介したが，本稿ではその後の半年間 (1976年 1 月～6月）分の中から主なものを抄録した.

ソ連は1965年 7 月 1 日に工業所有権に関するパリ同盟 条約に加盟し，特許に関してアメリカ，イギリスフフラ ンス，西ドイッ，日本などと国際的に全く同等の取扱、 を受けることになったのはもちろんであるが，1967年 6 月ストックホルムで行われたパリ同盟条約改正会議で発 明者証と特許が公知文献として国際的に同等の効果を有 することが認められた．このために，無効審判請求のた めの公知文献としてソ連特許や発明者証が極的て効果的 に利用されている。

重合体配合物 (to A. M. Shargorodskii et al.): USSR 498322, Novenber 1 (1974), January 5 (1976)

優れた密着性を示すとともに通気性の低い皮膜を得る ために，更にソルビン酸を次のような成分比（重量\%） で含有することを特徽とする．塩化ビニル（83～86重量 $\%$ ), 酶酸ビニル $(12.8 \sim 16.3$ 重量\%), 及びマレイン酸

(0.7 1. 2重量\%) から成る接着凧としての共重合体, 可塑剤としてのセバチン酸ジブチル, 充てん剂, 湿潤化 剈, 及び溶剂を含む重合体配合物

$\begin{array}{lc}\text { 共重合体 } & 10 \sim 20 \\ \text { 可塑剤 } & 1 \sim 4 \\ \text { 充てん剂 } & 0.5 \sim 1 \\ \text { 润滑化剂 } & 0.05 \sim 0.5\end{array}$

*技術情報コンサルタント

( 5547 大阪市平野区加美東 4-20-19)

\section{石 橋 喜代司 ${ }^{*}$}

ソルビン酸

溶剤
$0.5 \sim 1$

残り
合成ラテックスの製造方法 (to L. N. Afanaseva et al.): USSR 499278, June 28 (1974), January 15 (1976)

電解質の添加，及び機械的作用に対するラテックスの 安定性を高めるために, 脱気段階前にラテックス中に单 量体100重量部に対して1〜 5 重量部のメタクリル酸を 添加し、メタクリル酸とラテックスを接ぎ枝共重合さ せ，重合体中の重合されていない単量体の含量を $1 \sim 5$ \%としたことを特徴とする.ブタジェンとスチレンを水 エマルジョン遊離ラジカル共重合した後, 得られたラテ ックスから末重合の単量体を脱気することによる合成う テックスの製造方法.

変性されたポリウレタンゴムの製造方法（to Kazanskii khimiko-tekhnologicheskii institut im. S. M. Kirova): USSR 499281, June 24 (1976), January 15 (1976)

最終製品の耐熱性を高め，製造技術を単純化するため に，末端に NCO-基を有するオリゴウレタンを，八ロダ ン化されたポリオレフィン100重量部に対して2 5 重 量部の, 例えばへキサメチレンテトラミンのよ5な第 3 級アミン共存下で八ロゲン化されたポリオレフィンと反 応させることを特徴とする. 変性されたポリウレタンゴ 么の製造方法.

減摩性ポリカーボネート配合物 (to M. E. Savina et al.): USSR 499285, October 8 (1973), January 15 (1976)

耐摩耗性を高めるために，更にビニルリン酸のジー $\boldsymbol{\beta}$ ， 列ークロルエチルエステル，フェノール，及びホルムフ ルデヒドの縮合生成物 $(1: 3: 1.5 \sim 1: 3: 2.0)$ をにし み込ませた木綿織物, 若しくは木綿糸の粉末を次のよ5 
な成分比（重量\%）で含有することを特徴とする．ポリ カーボネートとポリフルオルオレフィンを含む減摩性ポ リカーボネート配合物.

$$
\begin{array}{lr}
\text { ポリカーボネート配合物 } & 22 \sim 85 \\
\text { ポリフルオルオレフィン } & 8 \sim 50
\end{array}
$$

木綿織物，若しくは木綿采の粉末 $4.95 \sim 28.75$
リン含有樹脂
$0.05 \sim 1.25$

ブタジエンニトリルゴムを基とするゴム配合物

(to Sredneaziztskii nauchno-issledovatelskii institut neftepererabatyvayushchei promyshlennosti): USSR 502917, June 14 (1971), February 15 (1976)

ゴムの耐油性を高めるために，可塑剤として酸素含有 化合物のエステル，エステルの重量に対して $3 \sim 5 \%$ の アルミニウムアルコレートで変性した上記エステル，若 しくは，多官能基型酸素含有化合物 $49.5 \sim 51.5$ 重量\%， 無水フタール酸25 27\%，及びグリセリン22.5 24.5重 量％を含有するポリエステルをゴム配合物に対して 9 $20 \%$ 含有することを特徴とする,ブタジェンニトリルゴ ムを基とするゴム配合物.

ポリジエンの製造方法 (to Institut vysokomolekulyarnykh soedinenii AN SSSR): USSR 503887, December 19 (1973), February 25 (1976)

各鎖中に重合安定剤を含有する重合体を製造するため に：ジェンと重合系中に添加された p- ベンゾキノンの 陰イオンブロック共重合をテトラヒドロフランのような 極性溶剂中で行うことを特徴とする，有機リチウム触媒 を用いて炭化水素系溶用中でイソプレンのようなジェン を重合することによるポリジェンの製造方法.

ゴム配合物 (to Moskovskii ordena Trudovogo Znameni institut neftekhimicheskoi i gazovoi promyshlennosti im. I. M. Gubkina): USSR 503892, April 2 (1974), February 25 (1976)

ゴムの耐寒性を高めるために，可塑㓣として10 13個 の炭菜原子を含む普通の構造の側鎖を有する一置換アル キルベンゼンをゴム100重量部に対して5 60重量部含有 することを特徴とする．合成ゴム，可塑剤，その他の添 加剂を含むゴム配合物.

クロロプレン重合体の製造方法（to Vsesoyuznyi nauchnoissledovatelskii i proektnyi institut polimernykh produktov): USSR 504798, April 8 (1974), February 28 (1976)

得られる重合体の安定性を高めるために，重合反応終 了後に，得られたラテックス中に重合体 100 重量部に対 して0.2 3.0重量部のエチレングリコールモノグリシジ
ルエステルを添加することを特徽とする. クロロプレン をエマルション重合, 若しくは, それを他の単量体と共 重合することによるクロロプレン重合体の製造方法.

\section{隇摩性自己潤滑材料をプレスするための配合物}

(to T. A. Zhraveleva et al.): USSR 504807, June 6

(1976), February 28 (1976)

通気性を低下させるとともに密度を高めるために，更 にフリル樹脂, 若しくは, フリルフルフラール重合体を 添加し，成分比（重量部）を次のようにしたことを特徽 とする，減摩性自己潤滑材料をプレスするための配 合 物.

$\begin{array}{ll}\text { 石炭瀝青 } & 15 \sim 25 \\ \text { 窒化ホウ素 } & 6 \sim 20 \\ \text { 2-フランカルビノール重合体 } & 4.5 \sim 7.5 \\ \beta \text {-オキシトリカルバリル酸 } & 0.35 \sim 0.70 \\ \text { 人造黒鉛粉末 } & 43 \sim 73 \\ \text { フリル檄脂 } & 1.5 \sim 4.5 \\ \text { オレイン酸 } & 0.2 \sim 0.6\end{array}$

帯電防止性組成物 (to Yu. I. Vasilenok et al.): USSR 510483, June 3 (1974), April 15 (1976)

帯電防止性と親水性を高めるために，ケイ酸，若しく は，二酸化ケイ素を添加し，成分比（重量\%）を次のよ らにしたことを特徽とする.エチレンの重合体，若しく は，共重合体と非イオン性界面活性剂を基とする帯電防 止性組成物。

エチレンの重合体，若しくは，

共重合体

$91.0 \sim 99.7$

非イオン性界面活性剂

$0.1 \sim 4.0$

ケイ酸，若しくは，二酸化ケイ素 $0.2 \sim 5.0$

重合体組成物 (to Yu. M. Mamatov et al.): USSR 510488, December 28 (1973), April 15 (1976)

耐化学薬品性を高めるために，結合材として2：0.5〜 $1.5: 0.5 \sim 1.5$ の成分比（重量部）でジフルフリリデンア セテート，フルフロール，及びフェノールホルムアルデ ヒド樹脂を縮合した生成物を使用し，硬化肪としてフリ ーデルクラフト触媒を次のような成分比（重量\%) で使 用することを特徽とする重合体組成物。

$\begin{array}{lr}\text { 結合材 } & 95 \sim 98 \\ \text { 硬化剂 } & 2 \sim 5\end{array}$

振動吸収性のバテ (to Vsesoyuznyi nauchnoissledovatelskii institut teploizolyatsionnykh i akusticheskikh stroitelhykh materialov i izdelii): USSR 512220, December 21 (1976), April 30 
(1976)

せい化温度を低下させるとともに，弾性と強度を増大 させるために，更にメタクリル酸メチルとクロロプレン を $7: 3$ の単量体比で重合させた共重合物の $42 \%$ 一分散 物と石綿，若しくは，ウール瀻維粉末を炊のような成分 比（重量％) で含有することを特徽とする．50\%一ポリ 酢酸ピニルエマルション，50\%ーフェノールアルコー ル，20\%一オルソリン酸，石英砂，及びタルクを含む振 動吸収性パテ.

$\begin{array}{lc}\text { ポリ酢酸ビニルエマルション } & 25 \sim 35 \\ \text { フェノールアルコール } & 14 \sim 22 \\ \text { オルソリン酸 } & 2 \sim 4 \\ \text { メタクリル酸とクロロプレンの } & \\ \text { 共重合体の分散物 } & 5 \sim 10 \\ \text { 石英砂 } & 14 \sim 26 \\ \text { タルク } & 14 \sim 26\end{array}$

石綿, 若しくは, ウール織維粉末 $1 \sim 4$

人造皮革を表面仕上げするための組成物（to

Vesoyuznyi nauchno-issledovatelskii institut plenochnykh materialov $i$ iskusstvennoi kozhi): USSR 513060, December 24 (1974), May 5 (1976)

人造皮革の加工性を高めるとともに，皮革の仕上げ技 街を単純化するために，分子量が30,000～70,000のポリ ウレタンと，変性鼡としてジェチルアミンを次のような 成分比（重量\%）で含有することを特徴とする．ポリウ レタン，溶剤，及び変性剤を含む，人造皮革を表面仕上 げするための組成物。

$\begin{array}{ll}\text { ポリウレタン } & 100 \\ \text { ジエチルアミン } & 0.05 \sim 5 \\ \text { 溶剤 } & 200 \sim 400\end{array}$

不能和ゴムを基とするゴム配合物 （to E： F. Burmistrov et al.): USSR 514865, December 13 (1972), May 25 (1976)

得られるゴムの耐熱性を高めるために，ジチオカルバ メートとしてへキサメチレンービスージチオカルバミン酸 の亜鉛䀅を次のよ5な成分比（重量部）で含有すること を特徵とする. チウラム，ジチオカルバメート，及びそ の他一般に使用される成分を含む，不鲍和ゴムを基とす るゴム配合物

$$
\begin{array}{ll}
\text { ヨ゙ム } & 100 \\
\text { チウラム } & 2.5 \sim 4 \\
\text { ヘキサメチレンービスージチオ } & \\
\text { カルバミン酸の亜鉛塩 } & 0.5 \sim 1.0
\end{array}
$$

ゴム配合物 （to Volgogradskii politekhnicheskii institut): USSR 516715, June 4 (1974), June 5 (1976)

ゴムの耐熱性を高めるために，安定化骩としてポリー (トリメチレンカルバミド) 一ホスフィンを次のような

\begin{tabular}{|c|c|}
\hline エ゙ム & 100 \\
\hline 可塑剂 & $0.7 \sim 1.2$ \\
\hline 促進㧩 & $2.5 \sim 5$ \\
\hline 活性化㓣 & $3 \sim 6$ \\
\hline 加硫剤 & $0.7 \sim 1.2$ \\
\hline ポリー(トリメチレンカルバ & \\
\hline ト) 一ホスフィン & $0.3 \sim 2$ \\
\hline
\end{tabular}
成分比（重量部）で含有することを特徴とする. 合成イ ソプレンゴム，可塑剤：促進成，活性化剂，加硫剤，及 び，安定化剤を含むゴム配合物。

隇摩性重合体組成物 (to Institut mekhaniki metallopolimernykh sistem AN Belorusskoi SSR): USSR 517607, July 3 (1974), June 15 (1976) 耐摩耗性と耐熱性を高め，摩擦係数を低下させるため に，更にポりビニルフルフラールとベンゾスルホン酸の 上5な触媒を次のような成分比（重量％）で含有するこ とを特徴とする．ポリプロピレンと黒鉛のような固体潤 滑剤を含む減摩性重合体組成物。

$\begin{array}{ll}\text { ポリプロピレン } & 60 \sim 84.9 \\ \text { ポリビニルフルフラール } & 10 \sim 20 \\ \text { 黒敛 } & 5 \sim 15 \\ \text { 触媒 } & 0.15 \sim 5\end{array}$

低分子量シロキサンゴムを基とする配合物（to V. V. Severnyi et al.): USSR 519457, March 29 (1974), June 30 (1976)

透明性を与えるために，一般式が，

$$
(\mathrm{RO})_{3} \mathrm{Si}\left(\mathrm{CH}_{2}\right)_{3} \text { OC } \mathbb{X}
$$

（ただし， $\mathrm{R}$ アアルキル基; $\mathrm{X}$-水素, $\mathrm{OCH}_{3}, \mathrm{OC}_{2} \mathrm{H}_{6}$ )で 表されるケイ素のアルコオキシ誘導体を次のよ5な成分 比（重量\%）で使用したことを特徽とする，触媒として の有機錫化合物とケイ素のアルコオキシ誘導体を含む， 低分子量シロキサンゴムを基とする配合物.

$$
\begin{array}{ll}
\text { シロキサンゴム } & 90.0 \sim 98.0 \\
\text { 有機スズ化合物 } & 0.1 \sim 0.9 \\
\text { ケイ素のアルコオキシ誘導体 } & 1.0 \sim 10.0
\end{array}
$$

〔付 記】ソ連特許情報に関する主な二次資料としては 下記が存在する。

(1) Derwent Information Service社(英)の「Soviet Inventions Illustrated」は，Derwent社の 7 部門別にソ連 
特許の技術抄録を揭载しているが，ソ連における公告日 から揭載されるまでほぼ 1 年を要するなど迅速さの点に 難がある。

(2) Research Information Service, Inc, (米)の rRussian Patent Bulletin」は，ソ連特許の分類を使用して書 誌的事項と明細書の全文英訳を揭载しているが，(1)と同 样に迅速さの点に難がある。

(3) Chemical Abstracts (*⿻丷木)

American Chemical Society が刊行している化学関係 の抄録誌で26加国の研究論文，技術資料，特許情報など の抄録が揭載されている.アメリカ，カナダ，西ドイ ソ，日本など一部の国の化学関係の特許は全部揭载され
ているが，ソ連の特許は公告されるるの全体の10 20\% しか揭载されていない，技術分野が化学に限定される 上，網睢的でないといら致命的な久陥がある。

(4). ソ連特許速報 (日)

著者が出している書誌的事項と特許請求の範囲を日本 語に翻訳して，ソ連に招ける公告日からほぼ1加月後に 継続的に提供するもので，迅速さの点で優れているばか りでなく国際特許分類（IPC）でどんなにせまい範囲に む限定できるといら利点を有している，我が国で日本語 凟料として入手できる唯一のソ連特許情報といわれてい る（日刊工業新閶昭和50年 4 月 1 日 13 面及び昭和52年 3 月 3 日 5 面や特許調査便覧 p. 559を参照のこと).
H1100299

\section{動物行動之地震予知}

Animal behaviour and erthquake prediction

地震が起る前に，動物が異常な行動をとることが以前 から報告されている、中国では動物を使った予知に力を 入れているが，この方法が他の前彫現象，たとえばP波 波/S波の速度比, 電気抵抗, ラドン含量, 電磁場, 静電 場などの変化と同しよ5に予知の有效な手段となるかど 5か検討するため，1976年10月23日～24日に米国カリフ オルニア州 Menlo Park で，米国地窝調查所(US Gelogical Survey)主催の動物行動と地触予知に関する会議が 開汃れた。

席上，様々な観察例が報告されたが，対象となる動物 はウシ，チンパンジ，人ビをはじめ広籁围にわたり；異 常行動と自然界の物理的, 化学的変化とがどの上 連をむつのか, 討論された。 また，何が異常な行動かと 認定するのもむずかしい問題であることが指摘された。

新しい断層に沿って生しる岩石破壊によって，地震エ ネルギーが解放されるが，その時，全てに同しよらな前 駆現象を伴らわけではないし，動物に動摇を起させる刺 激が全ての地震に必ず存在寸るわけでるない，いろいろ と考えられる刺激要因のらち，気圧，重力，海抜，傾斜
の変化は可能性がない.

米国地質調查所の D. Hill は，地震発生に伴う音が， その中心から数 $100 \mathrm{ft}$ 以内の筁囲にいる動物に刺激を与 えるかもしれないと指摘した. 地電流の変化は数ガンマ だけで，動きまわっておれば数10万ガンマの変化を経験 する動物に影響するとは考えられない，地表近くの地下 水位の変化も冬眠中のへビが穴からはい出す㖣明にはな るかもしれないが，不安行動の決定的要因とはなりえな い．静電場の変化やラドン放出との関係はまだよく調べ られていない.

結論として，動物行動利用した地震予知に次の三つ の方法があることが指掂された。

1) 異常行動を起すメカニズムが解明できなくても，地 震の前の行動の変化パターンが認識できれば，それを利 用する方法。

2)動物の生理的刺激を分析し，その物理的シグナルを 直接検知する方法.

LOGAN J M

D193B Nature 265 [5593] 404-405 (Feb. 3, '77)

〔日本科学技術情報センター発行「海外技術ハイライト」より 転载許可第文 -12 号了 